\title{
Cultural Contents in Two English Textbooks in Indonesia: Representations and Sources of Culture
}

\author{
Gisela Elshadelin \\ Filadelfia Christian School Surabaya \\ Email: fanuelgisel31@gmail.com \\ $\&$ \\ Mateus Yumarnamto \\ Widya Mandala Surabaya Catholic University \\ Email:mateus@ukwms.ac.id
}

\section{Article History \\ Received: \\ $05 / 15 / 2020$ \\ Reviewed: \\ $06 / 03 / 2020$ \\ Accepted: \\ $08 / 18 / 2020$}

Keywords:

cultural contents, ELT textbooks, local, global, Indonesia

DOI:

https://doi.org/10.33508/bw.v8i2.2511

\begin{abstract}
This study explores the representations of the cultural contents in English textbooks used in Indonesian contexts. The data sources for this study were two textbooks for grade 12 . The first one was Bahasa Inggris, a textbook published and endorsed by Indonesian government and the other one was Think, an international textbook published by Cambridge. Analyzing the two textbooks in terms of content analysis, we aimed at understanding different cultural sources represented in them. The findings show that the two textbooks have different emphasis regarding the culture they represent in texts and their accompanying visual illustrations. Bahasa Inggris puts the emphasis on global and local cultural sources. Other cultures that are not representative to the two main sources are very limited. On the other hand, Think provides a wide array of representations for global and other cultures but not local Indonesian culture. We end our discussion with a conceptual implication on cultural sources in English language teaching (ELT) materials.
\end{abstract}

\section{Introduction}

This study was conducted to explore how cultural contents were represented in two English textbooks, one published by a national publisher representing a local coursebook and the other one by Cambridge, used in Indonesian context representing a global coursebook. The representations of cultural contents in local and global coursebooks may bring different perspectives on how we see language teaching and how we see ourselves and the world. They may present "a particular view of reality and is value laden." (Garton \& Graves, 2014, p. 5)
In the context of teaching English as a foreign language in Indonesia, cultural contents are sensitive and could bring about tensions on learners and teachers. In one hand, foreign cultural contents are often admired and wanted but on the other hand suspicions do exist, creating a love-hate relationship to foreign language like English (Lauder, 2008).

In fact, based on the sources of culture, there are at least three main goals of the inclusion of cultural contents in English language teaching (ELT) materials: introducing the source culture (L1 Culture), 
introducing the target culture (L2 Culture), and introducing other cultures that do not belong to L1 or L2 culture (LO Culture) (Garton \& Graves, 2014; Messekher, 2014). The inclusion of the three cultural content sources in ELT textbooks is signified by the needs for cross cultural understanding and cultural awareness. As subsumed by Adaskou, Britten, and Fahsi (1990), the needs of cultural contents integration in ELT at least cover five areas of learners' needs: (1) to counter negative stereotype, (2) to better understand and appreciate L1 culture, (3) to facilitate possible visit to L2 countries, (4) to integrate interdisciplinary and thematic curriculum, (5) to motivate the learners. The five areas of learners' needs related to culture can fall into two categories, the needs of cross cultural understanding and the pedagogical needs. The first three fall into the first category of cross cultural understanding while the last two fall into the pedagogical needs.

Considering the importance of the cultural contents in ELT textbooks, the current study reports on how they are represented in two ELT textbooks used by students of Grade 12 in Indonesia. The first textbook, Bahasa Inggris, is a domestic English textbook - a textbook published in Indonesia for Indonesian students and it is endorsed by the Indonesian government. This textbook follows the national curriculum (The 2013 Curriculum). The second one, Think, is an international textbook published by Cambridge. It is widely used by private and public schools especially in urban areas in Indonesia. The Cambridge textbook follows the Cambridge curriculum and the Common European Framework of Reference for Languages (CEFR).

Examining the two different ELT textbooks, this study aims at finding out how different cultural sources are represented in them. The research question leading the inquiry is formulated as follows. How are the global culture (L1 culture), the local culture (L2 culture) and the other cultures (LO cultures) represented in the two ELT textbooks?

\section{Culture in English Textbooks}

\section{Literature Review}

Culture, as broadly define, is the products of human civilization that includes institutions, ideas, artifacts, and many other cultural aspects, the tangible and the intangible ones (Alonso \& Ponte, 2016; Baker, 2011; Weninger \& Kiss, 2013). In the context of foreign language education the inclusion of culture is generally accepted but debated in terms of whose culture to include and to what extent it can serve the purpose of language education. The debate related the inclusion of culture has been outline in three major stages, showing the development and progress of culture inclusion in foreign language teaching
(Weninger \& Kiss, 2013). The first stage is dated roughly between 1950 s to 1990 s where culture was understood as objects or artifacts or a set of facts need to be understood when students learn a foreign language. Learning culture in this stage was intended to immerse the learners in the target language culture. The second stage is between 1990s and 2000 when targeted culture is difficult to pinpoint because English has become an international language and the ownership of English was questioned as many different people from different countries speak the language. Finally, the third stage is from 2000 up to

Beyond Words Vol. 8, No. 2, November 2020 
present time where cultural hybridity and identity have taken shape by the advancement of information technology and the internet.

In each stage, we realized the importance of culture in language education and it is becoming more important with the complex interconnected cultural webs. As Messekher (2014) suggested, “culture, whether taught explicitly or implicitly, permeates many aspects of foreign language teaching" (p. 69). Therefore, learning a foreign language may involve learning different aspects of culture of the speakers of the language, of the future interlocutors, and of the global audience. In this case, the learners should be aware of various cultures that can affect their learning and their future. In the new reality where hybridity is the norm, various cultural aspects and their representations in English language materials and textbooks become more important.

Yuen (2011) highlights the importance of culture in language learning and how the representations of various cultural aspects in language textbooks are unavoidable when saying: "In general, learning a language involves learning different aspects of the culture in which the language is used and sometimes also how other cultures are represented in that particular culture because language depicts culture of its own and other cultures too. ... When learning a language, learners are also exposed to the cultures represented in these materials" (Yuen, 2011, p. 459).

The importance of culture and the context where the language is taught also echoed by Baker (2011) when he wrote, "Given the closely intertwined nature of culture and language, it is difficult to teach language without an acknowledgement of the cultural context in which it is used." (p. 62). From here, then we can ask about whose culture should be included to benefit language learners. McKay (2003) identified that local culture (L1 culture) should be included in teaching English as an international language. In supporting this idea, she asserted that one goal of learning a foreign language is communicating L1 culture to the international audience, making it central that English should be taught as an international language that can empower the learners.

The recognition of local culture is in line with the expanding scope of the purpose to learn a foreign language (Freeman, 2009). While in the first two stages of culture inclusion in language teaching (Weninger \& Kiss, 2013) power is not equally distributed to different cultures, the current practices acknowledge the power of L1 culture as equal and worthy for inclusion. Consequently, the shift of perspective and the expanding scope has changed the materials for English Language Teaching. There should be diversity and plurality among the cultures included in the materials (Toh, 2014). The inclusion of culture in ELT materials expands from the inner circle to the outer and to the expanding periphery.

The third stage of cultural inclusion (Weninger \& Kiss, 2013) in ELT addresses the reality of cultura franca (Gilmore, 2007, 2012, 2015), in which the inclusion of culture in ELT materials are detached of the association with the L1 culture and the L2 culture. The detachment can be done by putting English in the international context where the L1 and L2 culture cannot be easily identified and a form of hybridity of identity is taking place in the learners and the native speakers of the language. 
The Sources of Cultural Contents in ELT Materials

Considering the expanding scope of ELT and the expanding inclusion of various culture sources, Matsuda (2012) identified three sources of cultural contents in ELT materials: (1) the global culture, (2) the future interlocutors' culture, and (3) language learners' culture (L1 culture). While the last source is clear and can be easily identified, the first two sources of cultural contents can be problematic. What is meant by global culture and who are the future interlocutors? Matsuda, in this case, only acknowledged the problematic nature of the second source of culture, the future interlocutors. She did not acknowledge that the global culture, in fact, can be derived and developed from the center of global power, the inner circle, when we talk about English users.

With the caveats on the first two sources of cultural contents, we embrace Matsuda's definitions on the sources. First, global culture covers an array of cultural contents that cut across the international boundaries and consider universal. Issues such as world peace, global warming and other global issues such as the pandemic of Covid-19 are the examples of global issues that encompass the international boundaries. The inclusion of global cultural contents is intended to promote the learners' awareness as global citizens and to prepare them to communicate in English in the global context.

Second, the future interlocutors' culture refers to future English speakers from outside the inner circle which are not from the learners' culture. In short, the difficulties to identify the future interlocutors provide a wide array of future interlocutors' culture. For Indonesian learners, future interlocutors can be Singaporean, or Thai, or Brazilian, or various people from African countries. They can be future interlocutors for Indonesian and their cultures are worth to learn and included in the ELT materials. The inclusion of the future interlocutors' culture in ELT materials may enhance intercultural competence and cross-cultural understanding.

Finally, the learners' culture or local culture (L1 culture) refers to the culture belongs to the learners. In the case of Indonesian learners, the L1 culture is Indonesian culture that covers various subcultures within Indonesia. For the learners, the cultural contents from their own culture will be beneficial since they are familiar with the issues. These familiar cultural contents can motivate the learners and improve the interaction between teacher and learners (McKay, 2003). These L1 cultural contents can also reinforce their national identity as well as promoting and communicating their own culture to the global audience (Gilmore, 2007; Yuen, 2011).

\section{Cultural Contents in ELT Materials}

Cultural contents in ELT materials can be represented in various ways and forms. Yuen (2011) identified four major cultural contents in ELT materials: (1) products, (2) practices, (3) perspectives, and (4) persons. Products are the traditional forms of cultural contents; they are artifacts of culture such as food, fashion, works of arts and literature as well as various forms of entertainment in the society. Practices refer to socio-cultural practices done and maintained by the members of a community. They include customs, laws, ways of life, and other aspects of socio-cultural practices in the society. Perspectives are more abstract entities referring to the ways people see the

Beyond Words Vol. 8, No. 2, November 2020 
worlds. The world views generate abstract ideas such as democracy, feminism, capitalism, and many other ideas which can also shape and reshape the world views of a society. Finally, persons can be a representative of a culture in that the persons are culturally influential and famous and he or she could show a cultural identity representing his or her community.

Besides the cultural aspects of textbooks, there are cultural topics that can be used to analyze further the cultural contents. The categorization was made by Alonso and Ponte (2016). The cultural topics which they proposed cover everyday living, cultural heritage, national identity, popular culture, society, geography, stereotypes, language, worldwide issues, institution and organization, varieties, and social interaction. Alonso and Ponte's found that everyday living topics such as food, fashion, and festivals are the most common cultural contents found in ELT textbooks. The food and beverages that usually appear in textbooks are wine, coke, pasta, tea, and junk food.

\section{Research Methods}

This study is a qualitative content analysis of texts and visual illustrations. We follow Krippendorf $(1989,2004)$ in defining content analysis as it "seeks to analyze data within a specific context in view of the meanings someone - a group or a cultureattributes to them." (1989, p. 403). The goal of this study is to describe the meanings of
In ELT materials, cultural contents can be found in texts and on visual illustrations. Stories, news reports, and other written genres introduced to the students can bring the cultural contents. Similarly, illustrations, which are not only decorations (Romney, 2012), can be a powerful media to bring cultural contents to the learners. Visual images offer the universal language, which can be easily interpreted and understood, even by a novice learners of English (Elmiana, 2019). Considering that both textual and visual cultural contents can be powerful to shape the learners' world views, this current study reports the cultural contents on both textual and visual contents.

The inclusion or exclusion of cultural contents in an English textbook may reflect the worldview of the producers (Tomlinson, 2012). Therefore, the users, especially English language teachers should see the textbooks they use critically as they may not only communicate the face value of the intended contents but also the hidden values that the producers want to communicate to their audience.

messages and symbols found in the reading texts and illustrations of two ELT textbooks. Therefore, this study is more interpretative to the cultural contents representations found in the two textbooks. The lens we used to understand the meanings was the sources of cultural contents as suggested Yuen (2011) and Matsuda (2012). 

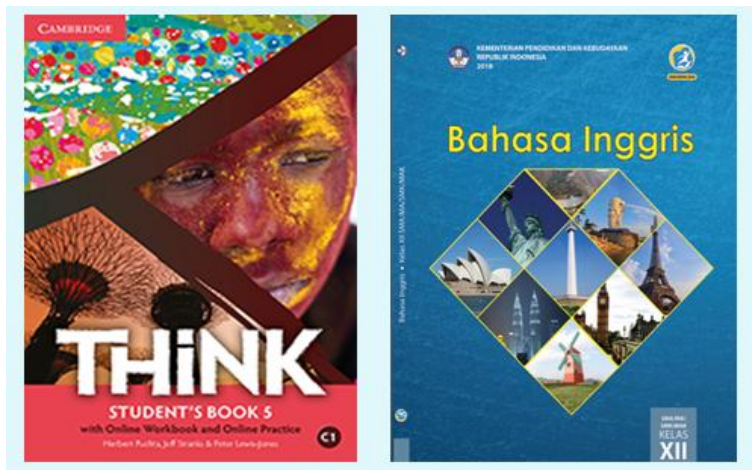

Fig. 1. The Sources of Data

textbooks). It represented a global coursebook as it was intended for international audience. It was our intention

Table 1

The Local and Global ELT Textbooks as Data Sources

\begin{tabular}{|c|c|c|c|}
\hline NO & BOOK TITLE & AUTHORS & DESCRIPTION \\
\hline & $\begin{array}{l}\text { Think } \\
\text { (Presentation Plus 5) }\end{array}$ & $\begin{array}{ll}\text { - } & \text { Herbert Puchta } \\
\text { - } & \text { Jeff Stranks } \\
\text { - } & \text { Peter Lewis-Jones }\end{array}$ & $\begin{array}{ll}\text { - } & \text { Based on Cambridge } \\
& \text { Curriculum } \\
\text { - } & \text { Student Book } \\
\text { - } & 12 \text { Units, } 128 \text { pages } \\
\text { - } & \text { Global Textbook }\end{array}$ \\
\hline & 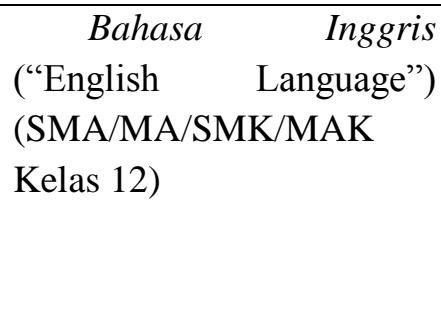 & $\begin{array}{ll}\text { - } & \text { Utami Widiati } \\
\text { - } & \text { Zuliati Rohmah } \\
\text { - } & \text { Furaidah }\end{array}$ & $\begin{array}{ll}\text { - } & \text { Indonesian national } \\
& \text { Curriculum (The } 2013 \\
& \text { Curriculum) } \\
\text { - } & \text { Student Book } \\
\text { - } & 16 \text { Chapters, } 256 \text { pages } \\
\text { - } & \text { Local Textbook }\end{array}$ \\
\hline
\end{tabular}

Bahasa Inggris has 16 chapters and 256 pages. In each chapter, there are at least two reading passages with follow-up activities such as writing and discussion, vocabulary, and pronunciation. Think consists of 12 chapters and 128 pages. Each chapter typically has a reading passage followed by reading comprehension section and other activities, such as vocabulary as well as discussion for speaking and writing. In addition, a cultural section is embedded in each chapter. Both textbooks have rich illustrations that usually represent and illustrate the corresponding reading passages for contexts and enrichment.

The main data for this study were focused on cultural contents found in the reading passages taken from the two textbooks as well as the illustrations companying the reading passages. The data, therefore, were in the forms of textual data and visual illustration data. The unit of analysis for the textual contents was the reading passage. For the visual illustrations, the unit of analysis was the picture or photo. The data were collected, abstracted and coded for further analysis by using Matsuda's (2012) framework on the sources of cultural contents in English language teaching materials. She suggests that there are three major sources of cultural contents: (1) the global culture, (2) the culture(s) of the future interlocutors and (3) the learners' own culture.

Beyond Words Vol. 8, No. 2, November 2020 Graduate School, Widya Mandala Surabaya Catholic University 
However, for the purpose of this study, what is meant by the global culture includes the L2 culture as reflected in our criticism to the vague meaning of the term global culture. As we believe, the global culture has developed from the very culture of the inner circle of English speakers. The attitude, however, has been changed in that the culture is intended to raise the awareness that we are global citizens and as human beings, we live in the same boat and face the same problems. The second note on the sources of cultural contents is related to the future interlocutors. As they are also difficult to determine in terms of the current L1 in Indonesia, we interpreted future interlocutors' culture as similar to other culture (L0 culture) the culture that does not belong to L1 culture (the learners' culture) and L2 culture (English native speakers' culture).

In addition, we also used the four aspects of culture as summarized by Yuen (2011) the four aspects include: (1) products, (2) practices, (3) perspectives, and (4) persons. More detailed descriptions on the categorization can be found in Alonso and Ponte (2016) in which they suggested a wide array of cultural topics. These topics

Findings a

The central question of this study is to identify how different sources of cultural contents are represented in the two ELT textbooks used in Indonesia, Bahasa Inggris, a textbook endorsed by the government to be used national wide, and Think, a textbook published by Cambridge. To answer the central question, the representations of global culture, local culture, and other culture are presented below. were also used to align the topics found in the reading passages and visual illustrations in the two textbooks.

In analyzing the data the writers followed these steps. First of all, the writers put a sign mark to the page which has the reading passage and visual illustrations. After that, the writers read the reading passage and made a summary of the reading. For the illustration, the writers made notes by describing the illustration. Then, the writers identified the sources and the aspects of cultural contents inside the reading passage and the illustration. After identifying the cultural contents, the writers classified the sources and the aspects of the cultural content in terms of Yuen's (2011) and Matsuda's (2012) framework.

To minimize biases in analyzing the data, triangulation was conducted by having the two triangulators to confirm some problematic areas in the analyses of the data. The two triangulators were English teachers who used the textbooks in the teaching. The problematic areas among others were in in determining the cultural sources, especially the global culture. These problematic areas were solved by involving the triangulators for their second opinions.

\section{The Representations of Global Culture}

The global culture, while indicating the wide acceptance of certain practices, products, and ideas as a result of a culture, in fact can be traced back to the inner circle, where powerful countries expand their cultural influence. Therefore, in the analysis, what is meant by L2 culture (the target language culture) can overlap with the global culture in a wide proportion (see Table 2 and 3). 
Table 2

The Representations of Global Culture in Bahasa Inggris

Bahasa Inggris (Endorsed by the Indonesian Government)

\begin{tabular}{|c|c|c|c|c|c|}
\hline \multirow[b]{2}{*}{ NO } & \multirow{2}{*}{$\begin{array}{l}\text { READING } \\
\text { TEXTS/ } \\
\text { ILLUSTRATIONS }\end{array}$} & \multicolumn{4}{|c|}{ Cultural representation in the texts/visual illustrations } \\
\hline & & Product & Practice & Perspective & Person \\
\hline \multirow[t]{2}{*}{$1 \mathrm{a}$} & $\begin{array}{l}\text { Six Things to Do if } \\
\text { You Visit Seattle }\end{array}$ & $\begin{array}{l}\text { Places: places to } \\
\text { visit in Seattle } \\
\text { (restaurants, cafe, } \\
\text { coffeehouses, } \\
\text { boutiques, galleries, } \\
\text { harbor) }\end{array}$ & $\begin{array}{l}\text { Travelling: } \\
\text { visiting places } \\
\text { for leisure, } \\
\text { vacationing }\end{array}$ & $\begin{array}{l}\text { Worldview: } \\
\text { enjoy your } \\
\text { life by } \\
\text { visiting } \\
\text { places }\end{array}$ & Unknown \\
\hline & & $\begin{array}{l}\text { Food: Chocolate, } \\
\text { coffee }\end{array}$ & $\begin{array}{l}\text { Promotion: } \\
\text { promoting tourist } \\
\text { destinations } \\
\text { using flyer or } \\
\text { brochure. }\end{array}$ & & \\
\hline $1 \mathrm{~b}$ & $\begin{array}{l}\text { Accompanying } \\
\text { illustrations }\end{array}$ & $\begin{array}{l}\text { Places: Farmers' } \\
\text { market, gallery, } \\
\text { chocolate factory }\end{array}$ & $\begin{array}{l}\text { Practice: Buying } \\
\text { and selling in a } \\
\text { market place. }\end{array}$ & & $\begin{array}{l}\text { Unknown } \\
\text { White }\end{array}$ \\
\hline & & $\begin{array}{l}\text { Product: cruise } \\
\text { ship }\end{array}$ & & & \\
\hline $2 \mathrm{a}$ & $\begin{array}{l}\text { Job application } \\
\text { (email) }\end{array}$ & $\begin{array}{l}\text { Product: email/job } \\
\text { application, } \\
\text { computers, internet }\end{array}$ & $\begin{array}{l}\text { Doing Business: } \\
\text { writing job } \\
\text { application }\end{array}$ & $\begin{array}{l}\text { Worldview: } \\
\text { improve your } \\
\text { career }\end{array}$ & $\begin{array}{l}\text { Common } \\
\text { people }\end{array}$ \\
\hline & & & $\begin{array}{l}\text { Doing Business: } \\
\text { working } \\
\text { computer skills }\end{array}$ & & \\
\hline $2 \mathrm{~b}$ & No illustration & & & & \\
\hline $3 \mathrm{a}$ & Bullying & $\begin{array}{l}\text { Product: academic } \\
\text { writing on bullying }\end{array}$ & $\begin{array}{l}\text { Academic } \\
\text { writing: } \\
\text { expository } \\
\text { writing } \\
\text { explaining a } \\
\text { phenomenon. }\end{array}$ & $\begin{array}{l}\text { Worldview: } \\
\text { bullying is } \\
\text { our problem } \\
\text { at schools }\end{array}$ & $\begin{array}{l}\text { Unknown, } \\
\text { students, } \\
\text { teachers }\end{array}$ \\
\hline
\end{tabular}

3b No illustration

Notes: The descriptions here exemplify how global culture incorporated in the text and illustrations. It is not intended to exhaustively describe all the cultural contents and sources found in Bahasa Inggris. 
Table 3

The Representations of Global Culture in Think

\begin{tabular}{|c|c|c|c|c|c|}
\hline \multicolumn{6}{|c|}{ Think (Published by Cambridge) } \\
\hline \multirow[b]{2}{*}{ NO } & \multirow{2}{*}{$\begin{array}{l}\text { READING } \\
\text { TEXTS/Illustrations }\end{array}$} & \multicolumn{4}{|c|}{ Cultural representation in the texts/visual illustrations } \\
\hline & & Product & Practice & Perspective & Person \\
\hline $1 \mathrm{a}$ & A Helping Hand & $\begin{array}{l}\text { Product: } \\
\text { airplane }\end{array}$ & $\begin{array}{l}\text { Travelling: } \\
\text { travelling by } \\
\text { plane }\end{array}$ & $\begin{array}{l}\text { Worldview: } \\
\text { Autism is a } \\
\text { global problem }\end{array}$ & Unknown \\
\hline & & $\begin{array}{l}\text { Place: on an } \\
\text { airplane }\end{array}$ & & $\begin{array}{l}\text { Idea: Be kind } \\
\text { to others, help } \\
\text { others in needs. }\end{array}$ & \\
\hline $1 \mathrm{~b}$ & $\begin{array}{l}\text { A mother and a son } \\
\text { in an airplane with a } \\
\text { laptop }\end{array}$ & $\begin{array}{l}\text { Product: } \\
\text { airplane, laptop }\end{array}$ & $\begin{array}{l}\text { Travelling: } \\
\text { travelling by } \\
\text { plane }\end{array}$ & & $\begin{array}{l}\text { Unknown } \\
\text { (White, } \\
\text { Western) }\end{array}$ \\
\hline $2 \mathrm{a}$ & News Mad? & $\begin{array}{l}\text { Product: TV, } \\
\text { Media }\end{array}$ & $\begin{array}{l}\text { Daily life: } \\
\text { watching TV }\end{array}$ & $\begin{array}{l}\text { Worldview: } \\
\text { news is } \\
\text { ubiquitous, } \\
\text { news is } \\
\text { everywhere }\end{array}$ & Unknown \\
\hline
\end{tabular}

\begin{tabular}{|c|c|c|c|c|c|}
\hline & & & & $\begin{array}{l}\text { Idea: Be } \\
\text { careful with TV } \\
\text { and news } \\
\text { media }\end{array}$ & \\
\hline \multirow[t]{2}{*}{$2 b$} & $\begin{array}{l}\text { Abstract image: } \\
\text { various news } \\
\text { media/TV channels }\end{array}$ & $\begin{array}{l}\text { Product: TV, } \\
\text { Media, TV } \\
\text { channels }\end{array}$ & $\begin{array}{l}\text { Daily life: } \\
\text { watching TV }\end{array}$ & $\begin{array}{l}\text { Worldview: } \\
\text { news is } \\
\text { ubiquitous, } \\
\text { news is } \\
\text { everywhere }\end{array}$ & $\mathrm{n} / \mathrm{a}$ \\
\hline & & & & $\begin{array}{l}\text { Idea: } \mathrm{Be} \\
\text { careful with TV } \\
\text { and news } \\
\text { media }\end{array}$ & \\
\hline \multirow[t]{2}{*}{$3 a$} & $\begin{array}{l}\text { Pride and Prejudice } \\
\text { (summary) }\end{array}$ & $\begin{array}{l}\text { Product: Work } \\
\text { of literature }\end{array}$ & $\begin{array}{l}\text { Daily life: } \\
\text { Reading novel } \\
\text { (literature } \\
\text { work) }\end{array}$ & Idea: Love & $\begin{array}{l}\text { Famous } \\
\text { person: Jane } \\
\text { Austen } \\
\text { (Writer) }\end{array}$ \\
\hline & & $\begin{array}{l}\text { Place: setting } \\
\text { in UK }\end{array}$ & & & \\
\hline $3 b$ & $\begin{array}{l}\text { Picture of Elizabeth } \\
\& \text { Darcy (the } \\
\text { characters in Pride } \\
\text { and Prejudice) }\end{array}$ & $\begin{array}{l}\text { Product: Work } \\
\text { of literature }\end{array}$ & & Idea: Love & $\begin{array}{l}\text { Characters in } \\
\text { the novel: } \\
\text { Elizabeth } \\
\text { and Darcy. }\end{array}$ \\
\hline
\end{tabular}

Notes: The descriptions here exemplify how global culture incorporated in the text and illustrations. It is not intended to exhaustively describe all the cultural contents and sources found in Think. 
Typically, the global culture represented in Bahasa Inggris is in the forms of travel brochure, email, and academic or scientific reports on a certain phenomenon, such as bullying. There is no work of literature introduced in Bahasa Inggris as the representative of the global culture. This may reflect the wide audience of the textbooks, Indonesian students all over the country with varying degree of English.

In Think, on the other hand, global culture is represented in various topics and genres, from sports, to arts, to literature, and to famous people. This wide array of representations may also reflect the nature of the intended audience of the textbook, students living in urban areas studying in private schools. In short, the audience of the textbook is highly expected to encounter with the global culture or the target culture in person.

\section{The Representations of Local Culture}

What is meant by local culture in this study is the Indonesian culture, which is not monolithic but diverse. Therefore, identifying local culture includes all cultural sources that can be traced back to any locations in Indonesia. Table 4 and 5 describe the representations of local cultures found in the two textbooks.

\section{Table 4}

\section{The Representation of Local Culture in Bahasa Inggris}

\begin{tabular}{|c|c|c|c|c|c|}
\hline \multirow[b]{3}{*}{ NO } & \multicolumn{5}{|c|}{ Bahasa Inggris (Endorsed by the Indonesian Government) } \\
\hline & \multirow{2}{*}{$\begin{array}{l}\text { READING } \\
\text { TEXTS/ } \\
\text { Illustrations }\end{array}$} & \multicolumn{4}{|c|}{ Cultural representation in the texts/visual illustrations } \\
\hline & & Product & Practice & Perspective & Person \\
\hline \multirow[b]{2}{*}{$\mathrm{a}$} & Baduy People & Product: & Custom: & Worldview: & Unknown \\
\hline & & $\begin{array}{l}\text { Baduy } \\
\text { clothes, } \\
\text { houses }\end{array}$ & $\begin{array}{l}\text { Baduy people's } \\
\text { customs: rejecting } \\
\text { modern life, live a } \\
\text { simple life }\end{array}$ & $\begin{array}{l}\text { Life is simple for } \\
\text { Baduy } \\
\quad \text { Idea: From } \\
\text { the outsider, the life } \\
\text { of Baduy people is } \\
\text { interesting and can } \\
\text { become tourist } \\
\text { attraction } \\
\text { (economy and } \\
\text { exploitation) }\end{array}$ & Baduy people \\
\hline $\mathrm{b}$ & $\begin{array}{l}\text { Picture of Baduy } \\
\text { Village }\end{array}$ & $\begin{array}{l}\text { Product: } \\
\text { houses, } \\
\text { clothes }\end{array}$ & & & $\begin{array}{l}\text { Unknown } \\
\text { Baduy people }\end{array}$ \\
\hline $\mathrm{a}$ & $\begin{array}{l}\text { News report on the } \\
\text { action of Indonesian } \\
\text { Army in fighting } \\
\text { illegal logging }\end{array}$ & $\begin{array}{l}\text { Product: } \\
\text { military }\end{array}$ & $\begin{array}{lr}\text { Practice: } & \text { military } \\
\text { responsibility } & \text { in } \\
\text { fighting } & \text { illegal } \\
\text { logging } & \end{array}$ & $\begin{array}{l}\text { Idea: } \\
\text { logging } \\
\text { threatened } \\
\text { ecosystem and the } \\
\text { future of Indonesia }\end{array}$ & $\begin{array}{l}\text { Major General } \\
\text { Subagyo } \\
\text { (military } \\
\text { commander) }\end{array}$ \\
\hline
\end{tabular}




\begin{tabular}{|c|c|c|c|c|c|}
\hline $\mathrm{a}$ & $\begin{array}{l}\text { Indonesia } \quad \text { Opens } \\
\text { Regional Recycling } \\
\text { Conference } \quad \text { (Nes } \\
\text { Report) }\end{array}$ & $\begin{array}{l}\text { Product: } \\
\text { government } \\
\text { system, waste } \\
\text { management } \\
\text { system }\end{array}$ & $\begin{array}{l}\text { Practice: } \\
\text { international } \\
\text { cooperation and } \\
\text { collaboration in } \\
\text { waste management }\end{array}$ & $\begin{array}{l}\text { Worldview: waste } \\
\text { is not only a local } \\
\text { problem, it is a } \\
\text { global problem }\end{array}$ & $\begin{array}{l}\text { Mayor Tri } \\
\text { Rismaharini }\end{array}$ \\
\hline & & & & $\begin{array}{l}\text { Idea: Waste } \\
\text { management } \\
\text { through } \\
\text { Reduce, Reuse, and } \\
\text { Recycle }\end{array}$ & \\
\hline b & $\begin{array}{l}\text { Mayor Tri } \\
\text { Rismaharini in the } \\
\text { conference }\end{array}$ & & $\begin{array}{l}\text { Practice: } \\
\text { international } \\
\text { cooperation and } \\
\text { collaboration in } \\
\text { waste management }\end{array}$ & & $\begin{array}{l}\text { Mayor Tri } \\
\text { Rismaharini }\end{array}$ \\
\hline
\end{tabular}

Notes: The descriptions here exemplify how global culture incorporated in the text and illustrations. It is not intended to exhaustively describe all the cultural contents and sources found in Bahasa Inggris.

\section{Table 5}

The Representations of Local Culture in Think

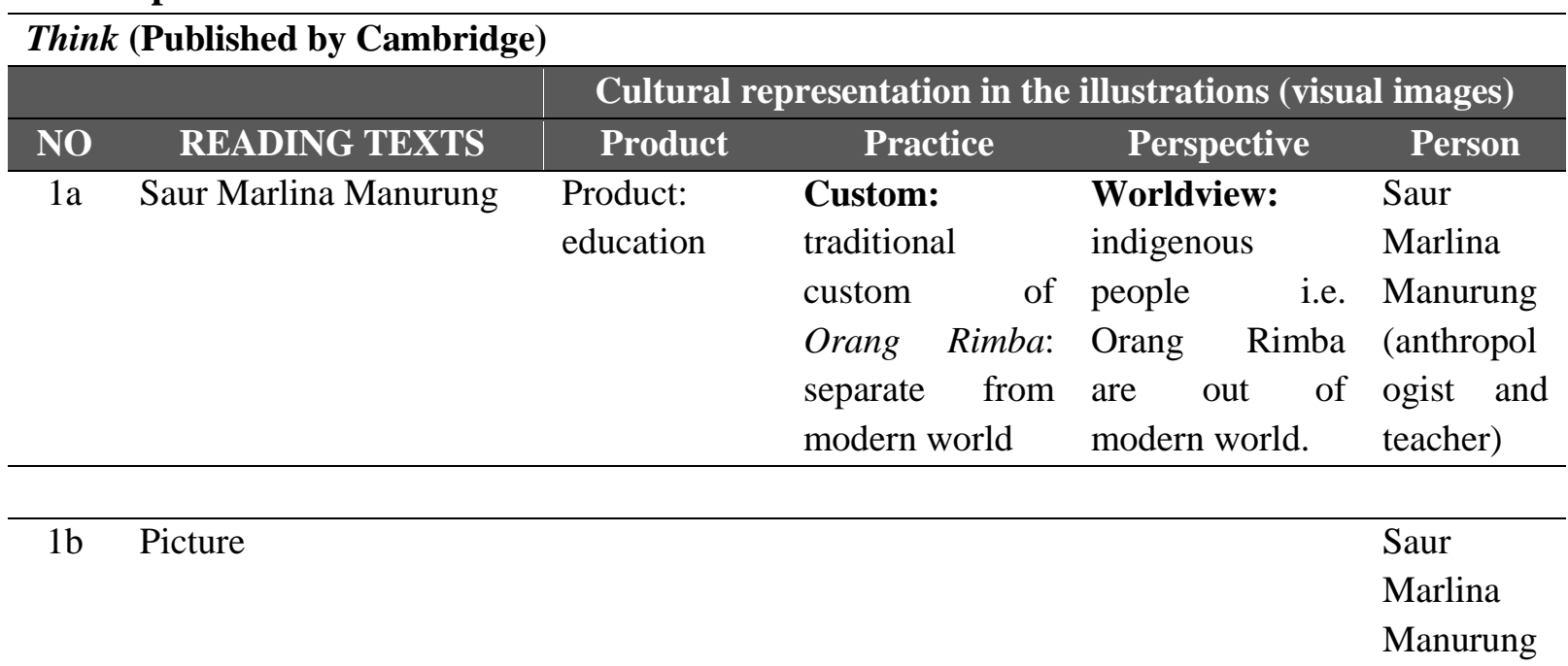

Notes: In Think, we only found one reading text that can represent Indonesian culture.

In Bahasa Inggris, the local culture is represented in a more diverse way, from different indigenous people living in Indonesia, such as Baduy People, to various news reports related to local governments, and environment. All those topics, as local or national issues, are presented to raise the awareness about various problems and issues encountered in Indonesia.
In contrast, Think has only one reading text that can be traced back to Indonesian culture. It is the text related to an activist and anthropologist Saur Marlina Manurung who teaches an indigenous people living deep in the forest. So, in terms of local culture, Think may underrepresent Indonesian cultures. Considering that the textbook is used by various private schools in big cities in Indonesia, this underrepresentation of local 
cultures can be a drawback of the book. However, the emphasis of the global culture can be understood as meeting the demands of the intended English learners using the textbook.

\section{The Representations of Other Cultures}

Other cultures are cultures that cannot be traced back to local culture and the

\section{Table 6}

\section{The Representations of Other Cultures in Bahasa Inggris}

\begin{tabular}{|c|c|c|c|c|c|}
\hline \multirow[b]{2}{*}{ NO } & \multirow[b]{2}{*}{ READING } & \multicolumn{4}{|c|}{ Cultural representation in the illustrations (visual images) } \\
\hline & & Product & Practice & Perspective & Person \\
\hline 1a & $\begin{array}{l}\text { Zebra } \\
\text { (expository } \\
\text { text } \\
\text { explaining } \\
\text { zebra) }\end{array}$ & $\begin{array}{l}\text { Product: } \\
\text { Oral history } \\
\text { and } \\
\text { etymology }\end{array}$ & & & \\
\hline
\end{tabular}

\begin{tabular}{llllll}
\hline \multicolumn{7}{c}{ Identity: } \\
Africa
\end{tabular}

$2 b \quad$ No

illustration

Notes: In Bahasa Inggris, we only found two readings texts that can represent other cultural sources. 


\section{Table 7}

The Representations of Other Cultures in Think

\begin{tabular}{|c|c|c|c|c|c|}
\hline \multicolumn{6}{|c|}{ Think (Published by Cambridge) } \\
\hline \multirow[b]{2}{*}{ NO } & \multirow[b]{2}{*}{$\begin{array}{l}\text { READING } \\
\text { TEXTS }\end{array}$} & \multicolumn{4}{|c|}{ Cultural representation in the illustrations (visual images) } \\
\hline & & Product & Practice & Perspective & Person \\
\hline $1 \mathrm{a}$ & $\begin{array}{l}\text { Multilingual } \\
\text { communities } \\
\text { around the } \\
\text { world }\end{array}$ & $\begin{array}{l}\text { Product: } \\
\text { Languages, } \\
\text { identity }\end{array}$ & $\begin{array}{l}\text { Daily life: The use } \\
\text { of more than one } \\
\text { language in many } \\
\text { different regions }\end{array}$ & $\begin{array}{l}\text { Worldview: } \\
\text { Multilingualis } \\
\mathrm{m} \text { is common }\end{array}$ & unknown \\
\hline $1 b$ & $\begin{array}{l}\text { Signs written in } \\
\text { different } \\
\text { languages }\end{array}$ & $\begin{array}{l}\text { Product: } \\
\text { Languages, } \\
\text { identity }\end{array}$ & $\begin{array}{l}\text { Daily life: The use } \\
\text { of more than one } \\
\text { language in many } \\
\text { different regions }\end{array}$ & $\begin{array}{l}\text { Worldview: } \\
\text { Multilingualis } \\
\mathrm{m} \text { is common }\end{array}$ & unknown \\
\hline $2 \mathrm{a}$ & $\begin{array}{l}\text { The world's last } \\
\text { uncontacted } \\
\text { tribes }\end{array}$ & $\begin{array}{l}\text { Product: } \\
\text { clothes, body } \\
\text { paintings }\end{array}$ & $\begin{array}{l}\text { Daily life: } \\
\text { traditional } \\
\text { unknown tribe in } \\
\text { the Brazilian- } \\
\text { Peruvian frontier. }\end{array}$ & $\begin{array}{l}\text { Idea: The } \\
\text { peace of } \\
\text { indigenous } \\
\text { people are } \\
\text { threatened }\end{array}$ & unknown \\
\hline $2 \mathrm{~b}$ & $\begin{array}{l}\text { A group of } \\
\text { people from } \\
\text { unknown tribe } \\
\text { photographed } \\
\text { from above }\end{array}$ & $\begin{array}{l}\text { Product: } \\
\text { clothes, body } \\
\text { paintings, bows } \\
\text { and arrows }\end{array}$ & $\begin{array}{l}\text { Daily life: } \\
\text { hunting, gathering }\end{array}$ & & unknown \\
\hline $3 \mathrm{a}$ & $\begin{array}{l}\text { Yvonne Bezerra } \\
\text { from Rio de } \\
\text { Janeiro }\end{array}$ & $\begin{array}{l}\text { Product: urban } \\
\text { city of Rio, }\end{array}$ & $\begin{array}{l}\text { Activism: helping } \\
\text { others by } \\
\text { educating }\end{array}$ & $\begin{array}{l}\text { Idea: Helping } \\
\text { the } \\
\text { disadvantaged } \\
\text { group of people } \\
\text { by education }\end{array}$ & $\begin{array}{l}\text { Yvonne } \\
\text { Bezerra } \\
\text { (activist) }\end{array}$ \\
\hline $3 \mathrm{~b}$ & $\begin{array}{l}\text { Pictures of } \\
\text { some human } \\
\text { right activists }\end{array}$ & & $\begin{array}{l}\text { Activism: helping } \\
\text { others by } \\
\text { educating }\end{array}$ & $\begin{array}{l}\text { Idea: Helping } \\
\text { the } \\
\text { disadvantaged } \\
\text { group of people } \\
\text { by education }\end{array}$ & Unknown \\
\hline
\end{tabular}

Notes: The descriptions here exemplify how other cultural sources are incorporated in the texts and illustrations. It is not intended to exhaustively describe all the cultural contents and sources found in Think

In Bahasa Inggris, other cultures are represented in two reading texts related to zebra and Persian pottery. These two textual representations may reflect the need of the targeted learners on more local and global culture. Other cultures, which may become future interlocutors of English, might not be considered the priority.

In Think, there are many textual representations introducing other cultures, from Africa, Latin America, and many different parts of the world where English is 
not spoken as the first language. This fact may represent more international audience of the book as it is also intended to be used in many different countries, not only in Indonesia.

\section{Implications of Different Cultural Representations in the Local and Global ELT Textbooks}

From Table 2 to 7 , we have learned different representations of cultural sources in the two textbooks examined in this study. We found that the emphasis of the two textbooks in representing the three cultural sources is different. Bahasa Inggris as written by Indonesian and are intended for Indonesian learners all over the country puts the emphasis on global and local culture. On the other hand, Think puts the emphasis on global and other cultures, with only one text containing the local culture of Indonesia. This different emphasis may be influenced by the intended target audience of the textbooks and the values that are intended to be communicated to the audience.

First, Bahasa Inggris as a local textbook provides adequate local (L1) and global cultural contents (highly overlapped with L2 culture) to the intended learners, Indonesian. It provides minimal contents on other cultures (L0 culture). This fact may reflect the alignment of the authors with the goal of English language teaching and the national agenda of Indonesian education. First, the goal of English language teaching in public schools is to prepare the students to use the language for international communication. This goal, as reflected by Lie (2017) is to prepare the students to compete in the global culture when she suggests:
The pressures of mastering English go hand in hand with the drive among the middle-class to push their children up the ladder of success in the globalized world. The urban middle-class parents believe that mastery of English would set their children ahead for the global competition. (p. 77)

While the local textbook is intended to prepare the learners to engage with the global community, it also serves the national agenda by representing adequate local cultural contents. In fact, the textbook has been developed based on the Indonesian national curriculum, which incorporates value education as a tool to promote character education and national identity and unity. Communicating local culture to global audience and maintaining national identity are two intended goals of teaching English as a foreign language in Indonesia. It reflects the imagined affiliation with the local and global community (Yumarnamto, 2017). Therefore, teachers need to be aware of the cultural representations and may need to supply what lacks in the textbook.

Second, Think put the emphasis on the global culture and the other cultures as it is intended for international audiences, not only for Indonesian. It is understandable then that it does not include adequate local cultural contents that reflect the learners' culture in Indonesia. Consequently, English teachers using this textbook should be aware that the lack of local cultural contents may disadvantage the learners as they need to maintain their local and national identity (Lie, 2017; Yumarnamto, 2017).

Third, considering the different representations of cultural contents in the local and global textbook as exemplified in Bahasa Inggris and Think, the users,

Beyond Words Vol. 8, No. 2, November 2020 Graduate School, Widya Mandala Surabaya Catholic University 
especially English teachers, should be aware that those two types of textbooks can be complimentary. There is no best textbook and there is no best teaching method. As English teachers we need to be aware of different agendas and ideologies that want to be exposed and communicated by the producers of the textbooks to the audience. As suggested by Song (2013), the ideological control and setting up agenda can be shown by the inclusion or exclusion of cultural contents. In this conception, the important implication is that English teachers should develop "constructive criticality" (Tomlinson, 2012, p. 165) when they select materials for their teaching.

Finally, from the findings, we identify the conception of cultural sources in the literature has not been clearly described. The traditional conception includes the three main cultural sources, the L1 culture, the L2 culture, and the L0 culture (Messekher, 2014; Yuen, 2011). To reflect the changing ownership of English, which has moved to the outer and expanding circle (B. B. Kachru, Kachru, \& Nelson, 2006; Y. Kachru \& Smith, 2008), the inclusion of global and future interlocutors' culture could complete the map (Matsuda, 2012). However, we have two points of criticisms in the conception. The first point is that global culture is often conceptualized in a taken-for-granted concept which is widely accepted. We found, however, what is meant by global culture is often overlapped with L2 culture, the culture developed from the inner circle, to outer circle, and to the expanding periphery. The second point of our criticism is the conception of future interlocutors' culture. The term 'future interlocutors' is a tricky and vague term. The future interlocutors do not exist in the time of speaking and we need to predict who will be the future interlocutors. Therefore, talking about the future interlocutors' culture may be nonsensical as the owners of the culture have not existed yet.

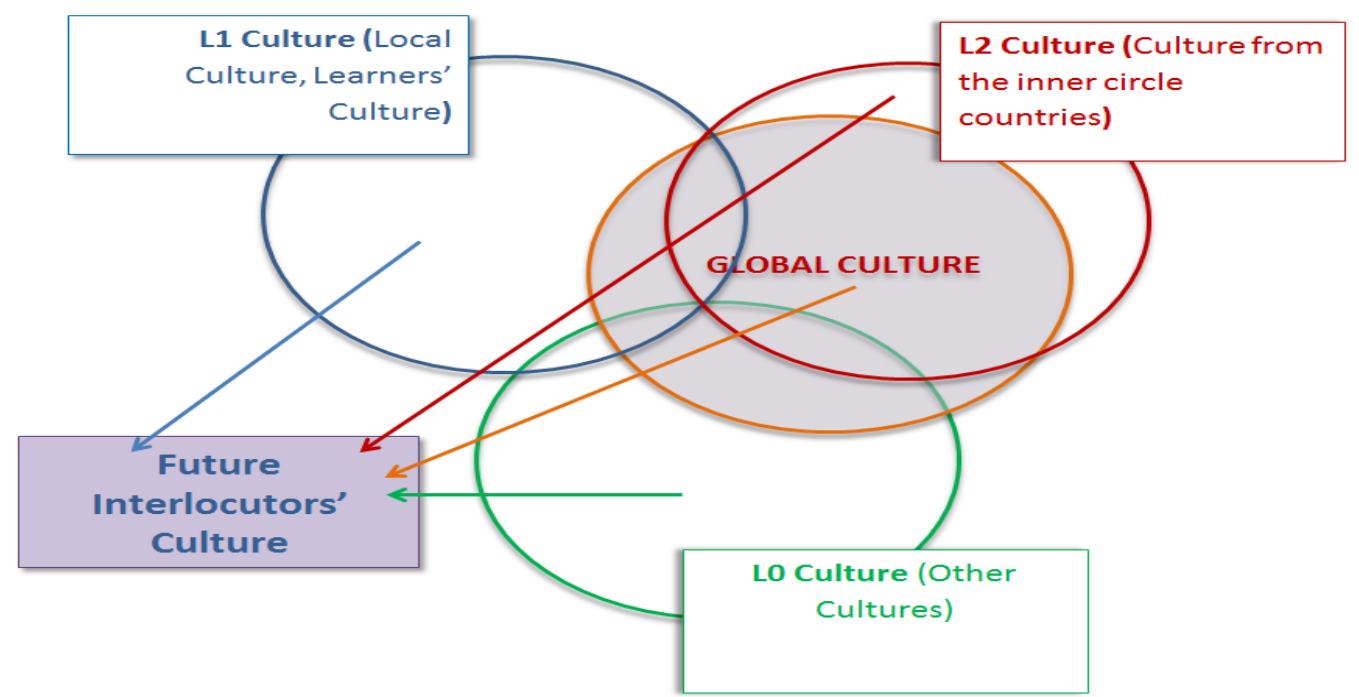

Fig. 2 A New Conception of Cultural Sources in ELT Materials

The implication of the findings along with our criticism to the conception of cultural sources brings to a new realization that we need a better conception of the cultural sources in ELT materials. What Matsuda (2012) identified as the three 
sources of cultural contents, the global, the local, and the future interlocutors seems not to align with what we found in the textbooks. The three sources should not be treated as separate sources but should be treated as interrelated and overlapped one. Upon looking at the data from this study, we suggest a new conceptualization with the emphasis on the expanding ownership of English as an international languagean interrelated and overlapped conception that can be described as the sources of culture in Figure 2.

In the new conceptualization, we have three main sources of culture, the L1, the L2, and the L0. The global culture is conceptualized as the expanding source originated in the L2 culture. The future interlocutors' culture, on the other hand, can be originated from any sources described above, making it the future mixed of the local culture, the global culture, and the other culture.

\section{Conclusion}

This exploratory study has examined the representations of different cultural sources in two English textbooks used in Indonesia, Bahasa Inggris and Think. In terms of cultural representations, we found out that the two textbooks have different emphasis regarding the culture they represent in texts and their accompanying visual illustrations. Bahasa Inggris, as written by Indonesians and for Indonesian learners put the emphasis on global and local culture. Other cultures that were very limited in the local textbook. On the other hand, Think provides a wide array of representations of global and other cultures, but not the local Indonesian culture.

The different representations of cultural sources in the local and global ELT textbooks used in Indonesian imply that the producers of the two textbooks may have different perspectives on the inclusion and exclusion of cultural contents. Different agenda may underlie the inclusion and exclusion, including the control of ideologies and agenda setting of the producers.

Finally, we suggest a new conceptualization of cultural sources in ELT materials. We move from the traditional conceptions to include the reality of the expanding ownership of English. However, different from Matsuda (2012) that substitute L2 with global culture and L0 with future interlocutors' culture, we suggest a complimentary conception to the traditional one, which reflect the reality of expanding ownership as well as the reality of the maintenance of the local identity and the inclusion of the imagined global community.

\section{References}

Adaskou, K., Britten, D., \& Fahsi, B. (1990). Design decisions on the cultural content of a secondary English course for Mororcco. ELT Journal, 44(1), 310. https://doi.org/10.1093/elt/44.1.3

Alonso, A. C., \& Ponte, D. C. (2016). EFL learners' cultural available lexicon: The effect of ELT textbooks. Revista de
Lenguas para Fines Específicos, 22(2), 177-201.

https://doi.org/10.20420/rlfe.2016.117

Baker, W. (2011). From cultural awareness to intercultural awareness: culture in ELT. ELT Journal, 66(1), 62-70. https://doi.org/10.1093/elt/ccr017 
Elmiana, D. S. (2019). Pedagogical representation of visual images in EFL textbooks: a multimodal perspective. Pedagogy, Culture \& Society, 27(4), 613-628.

https://doi.org/10.1080/14681366.2019. 1569550

Freeman, D. (2009). The scope of teacher education. In A. Burns \& J. C. Richards (Eds.), The Cambridge Guide to Second Language Teacher Education (pp. 1119). Cambridge: Cambridge University Press.

Garton, S., \& Graves, K. (2014). Materials in ELT: Current Issue. In S. Garton \& K. Graves (Eds.), International Perspectives on Materials in ELT (pp. 1-15). New York: Palgrave Macmillan.

Gilmore, A. (2007). Authentic materials and authenticity in foreign language learning. Kanguage Teaching, 40, 97118.

https://doi.org/10.1017/S026144480700 4144

Gilmore, A. (2012). Materials evaluation and design in language teaching. Language Teaching, 45(2), 250-262. https://doi.org/10.1017/S026144481100 0607

Gilmore, A. (2015). Research into practice: The influence of discourse studies on language descriptions and task design in published ELT materials. Language Teaching, 48(4), 506-530. https://doi.org/10.1017/s026144481500 0269

Kachru, B. B., Kachru, Y., \& Nelson, C. L. (2006). Introduction: The world of world Englishes. In B. J. Kachru, Y. Kachru, \& C. L. Nelson (Eds.), The Handbook of World Englishes (pp. 116). Oxford: Blackwell Publishing Ltd.
Kachru, Y., \& Smith, L. E. (2008). Cultures, Contexts, and World Englishes. New York: Routledge.

Krippendorff, K. (1989). Content analysis. In E. Barnouw, G. Gerbner, W. Schramm, T. L. Worth, \& L. Gross (Eds.), International Encyclopedia of Communication (Vol. 1, pp. 403-407). New York, NY: Oxford University Press. Retrieved from http://repository.upenn.edu/asc_papers/ 226

Krippendorff, K. (2014). Content Analysis: An Introduction to Its Methodology. New York: Sage Publications.

Lauder, A. (2008). The status and function of English in Indonesia: A review of key factors. Makara Sosial Humaniora, 12(1).

http://hubsasia.ui.ac.id/old/index.php/ hubsasia/article/view/128/82

Lie, A. (2017). English and identity in multicultural contexts: Issues, challenges, and opportunities. TEFLIN Journal, 28(1), 71-92. doi: 10.15639/teflinjournal.v28i1/71-92

Matsuda, A. (2012). Teaching materials in EIL. In L. Alsagoff, S. L. McKay, G. $\mathrm{Hu}, \quad \&$ W. A. Renandya (Eds.), Principles and Practices for Teaching English as an International Language (pp. 168-185). New York: Routledge.

McKay, S. (2003). Teaching English as an International Language: The Chilean context. ELT Journal, 57(2), 139-148. doi: https://doi.org/10.1093/elt/57.2.139

Messekher, H. (2014). Cultural Representations in Algerian English Textbooks. In S. Garton \& K. Graves (Eds.), International Perspectives on Materials in ELT (pp. 69-88). New York: Palgrave Macmillan. 
Romney, C. (2012). Images in ELT textbooks: Are they just decoration? Paper presented at the JALT 2011 Conference, Tokyo.

Song, H. (2013). Deconstruction of cultural dominance in Korean EFL textbooks. Intercultural Education, 24(4), 382390.

https://doi.org/10.1080/14675986.2013. 809248

Toh, G. (2014). The Cosmetics of Teaching English as an International Language in Japan: A Critical Reflectio. In R. Marlina \& R. A. Giri (Eds.), The Pedagogy of English as an International Language: Perspectives from Scholars, Teachers, and Students (pp. 175-187). New York: Springer.

Tomlinson, B. (2012). Materials development for language learning and teaching. Language Teaching, 45(2),
143-179.

https://doi.org/10.1017/s026144481100 0528

Weninger, C., \& Kiss, T. (2013). Culture in English as a foreign language (EFL) textbooks: A semiotic approach. TESOL QUARTERLY, 47(4), 694-716. https://doi.org/10.1002/ tesq.87

Yuen, K. M. (2011). The representation of foreign cultures in English textbooks. ELT Journal, 65(4), 458-466. https://doi.org/10.1093/elt/ccq089

Yumarnamto, M. (2017). English language teaching in Indonesia: Imagined communities and identities in borderless world. Paper presented at the The 10th International Conference: Revisiting English Language Teaching, Literature, and Translation in Borderless World, Salatiga, Central Java, Indonesia. 